Acta vet. scand. $1990,31,39-43$.

\title{
The Prevalence of Yersinia enterocolitica 0:3 in Finnish Pigs and Pork *
}

\author{
By $K$. Asplund, V. Tuovinen, P. Veijalainen and J. Hirn \\ National Veterinary Institute, Helsinki and Southwest Finland's Cooperative Slaughterhouse \\ (LSO), Turku, Finland.
}

\begin{abstract}
Asplund, K., V. Tuovinen, P. Veijalainen and J. Hirn: The prevalence of Yersinia enterocolitica 0:3 in Finnish pigs and pork. Acta vet. scand. 1990, 31, 39-43. - One hundred and forty seven samples of pig faeces collected from 14 herds located in different parts of Finland were examined for Yersinia enterocolitica biotype 4 serotype $0: 3$. Twenty six $(17.7 \%)$ animals and 5 herds $(35.7 \%)$ were positive. The tonsils of 350 animals from 35 herds with high condemnation figures at meat inspection and the tonsils of 131 animals from 13 herds with low condemnation figures collected from 2 abattoirs in southwest Finland were also examined. The prevalence raes of Y.e. in animals were $38.3 \%$ and $31.3 \%$ and in herds $74.3 \%$ and $61.5 \%$, respectively. The prevalence of $Y . e$. in herds with the high and low partial condemnation percentages did not differ significantly. No isolation of Y.e. was made from 104 samples of pork and minced pork collected from retail markets in Helsinki and from exporting slaughterhouses.
\end{abstract}

faeces; tonsils; condemnation figures.

\section{Introduction}

Yersinia enterocolitica is a ubiquitous gram negative bacterium, which has importance as a foodborne pathogen. It can grow at low temperatures and can cause chronic disorders in addition to the acute gastrointestinal disease. It has been isolated from many mammals, birds, fish and mollusks (Ahvonen et al. 1973, Kronstad 1974, Kapperud 1981, Fantasia et al. 1985, Shayegani et al. 1986, Chiesa et al. 1987). Yersinia enterocolitica is classified into serotypes based on thermostable $\mathrm{O}$-antigens and into biotypes based on biochemical properties (Niléhn 1970, Wauters 1973, Wauters et al. 1987). Only few of these serobiotypes are considered to have significance as human pathogens. The prevalence of positive antibody ti-

* This study has been supported by the Finnish Veterinary Science Foundation. ters against Yersinia in southwest Finland has been reported to be $17-43 / 100000$ (Leino 1982). In Belgium the isolation rate of Yersinia ssp. from routine stool cultures was 4\% (van Noyen et al. 1981).

The predominating serotypes in Europe are $0: 3$ and $0: 9$. The serotype $0: 3$ can frequently be isolated from pig tonsils and tongue but less frequently from faeces (Esseveld \& Goudzwaard 1973, Wauters 1979, Christensen 1980, Schiemann \& Fleming 1981, Nesbakken \& Kapperud 1985, Christensen 1986). The epidemiology of yersiniosis is still obscure, but it is obvious that pork has an important role as a source of infection. In Belgium, Tauxe et al. (1987) found an association between eating raw pork and Yersinia enterocolitica infections.

The aim of this study of to investigate the prevalence of Yersinia enterocolitica in pigs and pork and to test if there is any associa- 
between the prevalence of Yersinia and partial carcass condemnation figures at meat inspection.

\section{Material and methods \\ Faecal samples}

Faecal samples from 147 pigs were collected from 14 herds located in different parts of Finland during the fall and the winter 1987 88. No background information about the health status of the herds was available.

\section{Tonsil samples}

The tonsils were collected in 2 abattoirs located in southwest Finland during the summer and early fall of 1988 . Swine herds were feeder pig operations with an all-in-all-out system. They were divided into 2 groups based on the percentage of partially condemned carcasses. The control group (13 herds, 131 pigs) had low (0.63-1.69\%) and the case group (35 herds, 350 pigs) high (5.81$10.54 \%$ ) partial condemnation percentage. All farms had delivered more than 300 pigs in the previous year to these abattoirs.

\section{Pork samples}

Minced pork (46 samples) were bought from butcher shops mainly in Helsinki. Pork (58 samples) were collected in exporting slaughterhouses.

\section{Isolation}

Yersinia enterocolitica was isolated by using the method no. 117 of the Nordic Committee on Food Analysis (NMKL, 1987). Ten grams of both faeces and tonsils and $20 \mathrm{~g}$ of pork were used in the analysis.

\section{Biogrouping}

Biogrouping was done according to the revised scheme by Wauters et al. (1987). The properties tested were: esculin hydrolysis, production of acid from xylose and trehalose, $\beta$-D-glucosidase, proline peptidase, pyrazinamidase and lipase activities, indole, Voges-Proskauer and nitrate reduction. $\beta$ $D$-glucosidase and proline peptidase were incubated at $30^{\circ} \mathrm{C}$ and the rest at $25^{\circ} \mathrm{C}$. Other media were incubated for $20 \mathrm{~h}$, but esculin and sugars were incubated up to 10 days or until they were found to be positive.

\section{Serogrouping}

The specific 0:3-antiserum was prepared in rabbits according to Wauters (1981). The strains isolated were serotyped by slide agglutination.

\section{Statistics}

Chi-square test with Yates continuity correction was used to test if there was any difference in the prevalence of Yersinia enterocolitica $0: 3$ between case and control herds (tonsil samples).

\section{Results}

\section{Faecal samples}

Twenty six of the 147 faecal samples $(17.7 \%)$ were positive. Five herds out of 14 $(35.7 \%)$ had at least 1 positive animal.

\section{Tonsils}

Yersinia enterocolitica 0:3 was found in $36.4 \%$ of swine tonsils. At least 1 positive pig was found in $70.8 \%$ of the herds. The prevalence was a bit higher in the case group than in the control group, but the difference was not significant (Table 1).

\section{Pork}

Yersinia enterocolitica 0:3 was not found from any pork or minced pork sample. 


\begin{tabular}{|c|c|c|c|c|c|c|}
\hline \multirow{2}{*}{$\begin{array}{l}\text { Condemnation } \\
\%\end{array}$} & \multirow{2}{*}{$\begin{array}{c}\text { Total } \\
\text { no. of pigs }\end{array}$} & \multicolumn{2}{|c|}{ Positive pigs } & \multirow{2}{*}{$\begin{array}{c}\text { Total } \\
\text { no. of herds }\end{array}$} & \multicolumn{2}{|c|}{ Positive herds } \\
\hline & & no. & $\%$ & & no. & $\%$ \\
\hline Low & 131 & $41^{\mathrm{a}}$ & 31.3 & 13 & $8^{b}$ & 61.5 \\
\hline High & 350 & $134^{a}$ & 38.3 & 35 & $26^{b}$ & 74.3 \\
\hline All & 481 & 175 & 36.4 & 48 & 34 & 70.8 \\
\hline Chi-square & & $1.72^{\mathrm{a}}$ & & & $0.26^{b}$ & \\
\hline $\mathrm{p}$ & & 0.19 & & & 0.61 & \\
\hline
\end{tabular}

\section{Discussion}

The prevalence of Yersinia enterocolitica between the herds with low and high partial condemnation percentage did not differ significantly. This is in agreement with the results of Andersen (1984). He could not find significant association between the prevalence of Yersinia enterocolitica and different housing systems, feeding or frequency of sickness (measured by meat inspection findings).

At least 1 positive pig was found in $70.8 \%$ of farms in the study of tonsils. This is less than was seen by Andersen (1984), but more than the $33.3 \%$ that we found in an earlier study using 15 herds situated in different parts of the country (Asplund et al. 1988).

The prevalence rates found in this study are consistent with the rates found by Christensen (1980) in Denmark and Nesbakken \& Kapperud (1985) in Norway. This study cannot give complete information about the true prevalence of Yersinia enterocolitica 0:3 in the whole Finland, but it can be considered to represent the figures in southwest Finland with certain limitations. In our previous study (Asplund et al. 1988) we found that Yersinia enterocolitica could be isolated only from samples which were gathered from south and southwest Finland. Those 70 throat muscle samples were taken from 7 slaughterhouses situated in different parts of Finland. No statistical evaluation was performed on that material.
Swine density in southwest Finland is higher than in other parts of the country. About 35$40 \%$ of the Finnish pig population is housed in that area. Most of the feeder pig operations have all-in-all-out system. Slaughterhouses have organized the transport of feeder pigs from farrowing units to feeder pig operations. The minimum live weight of the transported feeder pigs is 20 kilograms. Feeder pigs are gathered from several farms to fill 1 feeder pig unit. Typically, feeder pigs from one farrowing unit end up in several finishing units. Thus Yersinia enterocolitica may be spread to several feeder pig operations from one farrowing unit (Christensen 1980). Hence, it might be worthwhile to study the epidemiology of Yersinia enterocoliti$c a$ in farrowing units.

Since 1986 the tonsils have been removed at the end of the slaughter process. It appears that contamination of meat during slaughter would not be very high, because no Yersinia enterocolitica 0:3 from pork or minced pork could be found.

There may be e.g. seasonal differences in occurrence of Yersinia, which cannot be seen in this study. We utilized samples which were originally gathered for other purposes and, therefore, sampling strategy was not optimal. This study can, however, be utilized to help in planning future studies with adequate sample size and sampling technique. 


\section{Acknowledgements}

The authors thank the meat inspectors Riitta Kääntee-Heuru, Pirjo Korpinen, Timo Laita, Tapio Lindstedt and Tuomas Varvikko for collecting the tonsil samples from the slaughterhouses of Forssa and Salo, and the employees of LSO Food Ltd. We also wish to thank associate professor Yrjö Gröhn and associate professor Barbara Straw from Cornell University for reading the manuscript.

\section{References}

Ahvonen P, Thal E, Vasenius H: Occurrence of Yersinia enterocolitica in animals in Finland and Sweden. Contr. Microbiol. Immunol. 1973, 2, 135-136.

Andersen JK: Humanpatogene Yersinia enterocolitica i danske svinebesætninger. (Human pathogenic Yersinia enterocolitica in Danish herds of pigs). $\mathrm{Ph}$.D. thesis. Institute of Hygiene and Microbiology. Royal Veterinary and Agricultural University. Copenhagen, Denmark 1984.

Asplund K, Siitonen A, Hirn J: Yersinia enterocolitica serobiotyyppi 0:3,4:n esiintyminen suomalaisissa sioissa. (The prevalence of Yersinia enterocolitica serobiotype 0:3,4 in Finnish pigs). Suomen Eläinlääkärilehti 1988, 94, 177-180.

Chiesa C, Dal Prà A, Guarneri G, Penso S, Rodella L, Volterra L, Zugno A: Survey on Yersinia enterocolitica and related bacteria in shellfish. Water, Air, and Soil Pollution 1987, 34, 241-244.

Christensen SG: Yersinia enterocolitica in Danish pigs. J. appl. Bacteriol. 1980, 48, 377-382.

Christensen SG: The Yersinia enterocolitica situation in Denmark. Conrib. Microbiol. Immunol. 1987, 9, 93-97.

Esseveld H, Goudzwaard C: On the epidemiology of Yersinia enterocolitica infections: pigs as a source of infections in man. Contr. Microbiol. Immunol. 1973, 2, 99-101.

Fantasia M, Mingrone MG, Crotti D, Boscato C: Isolation of Yersinia enterocolitica biotype 4 serotype 03 from canine source in Italy. J. clin. Microbiol. 1985, 22, 314-315.

Kapperud G: Survey of the reservoirs of Yersinia enterocolitica and Yersinia enterocolitica-like bacteria in Scandinavia. Acta Path. Microbiol. Scand. Sect. B, 1981, 89, 29-35.
Kronstad O: Yersinia enterocolitica infection in goat. A serological and bacteriological investigation. Acta vet. scand. 1974, 15, 597-608.

Leino $R$ : Human yersiniosis. A clinical study with special reference to lymphocyte transformation in Yersinia arthritis. Academic dissertation. Turku, 1982.

Nesbakken T, Kapperud G: Yersinia enterocolitica and Yersinia enterocolitica-like bacteria in Norwegian slaughter pigs. Int. J. Food Microbiol. 1985a, 1, 301-309.

Niléhn B: Studies on Yersinia enterocolitica. Acta Path. Microbiol. Scand., Suppl. 206, 1969.

Nordic Committee on Food Analysis (Nordisk Metodikkommité för livsmedel, NMKL): Yersinia enterocolitica. Detection in food. No. 117, 2nd edition, 1987.

van Noyen $R$, Vandepitte J, Wauters $G$, Selderslaghs $R$ : Yersinia enterocolitica: its isolation by cold enrichment from patients and healthy subjects. J. clin. Pathol. 1981, 34, 1052-56.

Schiemann DA, Fleming CA: Yersinia enterocolitica isolated from throats of swine in eastern and western Canada. Can. J. Microbiol. 1981, 27, 13261333.

Shayegani M, Stone WB, DeForge I, Root T, Parsons LM, Maupin P: Yersinia enterocolitica and related species isolated from wildlife in New York stae. Appl. Environ. Microbiol. 1986, 52, 420-424.

Tauxe $R V$, Wauters $G$, Goossens $V$, avn Noyen $R$, Vandepitte J, Martin SM, De Mol P, Thiers G: Yersinia enterocolitica infections and pork: the missing link. Lancet 1987, i, 1129-1132.

Wauters G: Carriage of Yersinia enterocolitica serotype 3 by pigs as a source of human infection. Cont. Microbiol. Immunol. 1979, 5, 249-252.

Wauters $G$ : Antigens of Yersinia enterocolitica. In Bottone: Yersinia enterocolitica. CRC Press, Boca Ration, 1981, 41-53.

Wauters $G$, Kandolo $K$, Janssens $M$ : Revised biogrouping scheme of Yersinia enterocolitica. Contr. Microbiol. Immunol. 1987, 9, 14-21. 


\section{Sammanfattning}

Prevalens av Yersinia enterocolitica 0:3 frän svin och svinköt i Finland.

Prevalens av Yersinia enterocolitica biotyp 4 serotyp 0:3 i fekala prov av 147 svin från 14 svingårdar liggande i olika delar av Finland undersöktes. Tjugoett $(17.7 \%)$ djur och $5(35.7 \%)$ svingårdar var positiva. Tonsiller av 350 svin från 35 svingårdar med höga partiella kasseringsprocenter vid köttbesiktiningen och 131 svin från 13 svingårdar med låga partiella kasseringsprocenter undersöktes också för Y.e. 0:3. Prevalensen i djur av den förstnämda gruppen var $38.3 \%$ och $\mathrm{i}$ den sistnämda gruppen $31.3 \%$. I den förstnämda gruppen var 26 svingårdar $(74.3 \%)$ positiva och i den sistnämda gruppen 8 (61.5\%). Man kunde inte finna någon signifikant skillnad mellan dessa två grupper. Y.e. kunde inte isoleras från 104 prov av svinkött.

(Received May 4, 1989; accepted May 26, 1989).

Reprints may be requested from: K. Asplund, National Veterinary Institute, P. O. Box 368, SF-00101 Helsinki, Finland. 